\title{
Increasing Efficiency of the Dye Degrading Bacteria by Plasmid Transfer Method
}

\author{
Rajesh M. Jorgewad* \\ Assistant Professor, Department of Biotechnology Engineering, KIT's College of Engineering (Autonomous), Kolhapur, \\ Maharashtra, India
}

*Address for Correspondence: Dr. Rajesh Mohanrao Jorgewad, Assistant Professor, Department of Biotechnology Engineering, KIT's College of Engineering (Autonomous), Kolhapur, 416234, India

E-mail: rajeshgudmalwar001@gmail.com

Received: 03 Jul 2018/ Revised: 04 Nov 2018/ Accepted: 25 Feb 2019

\begin{abstract}
Background: Two local strains of Bacillus sp. were isolated from industrial effluent and screened for dye degradation from industrial effluent. Bacillus sp. and $E$. coli isolated from effluents had a low capacity but high growth rate and these are aerobic microorganisms.

Methods: Both bacterial strains were used on the basis of resistant to either co-Trimoxzo or cephalexin antibiotics for the screening of transformed bacteria. Bacillus sp. and E. coli were sensitive and Pseudomonas sp. SUK1 was resistant to the same antibiotic respectively. Pseudomonas sp. SUK1 was used a as source of the plasmid (donor strain) to transform Bacillus sp. and E. coli. Competent bacterial cells were prepared by cold $\mathrm{CaCl}_{2}$ treatment while Heat shock method was used for transformation. Transformed bacteria were screened by using the antibiotic sensitivity test and agarose gel electrophoresis. These techniques lead to increased dye degradation capacity.

Results: Transformed E. coli was isolated and screened according to their antibiotic resistance and also found increased Red BLI (89.60\%) dye degrading capacity in aerobic condition.

Conclusion: The transformed bacteria can degrade $50 \mathrm{mg} \mathrm{l}^{-1}$ of individual dyes and even a mixture of dyes (which was actually the condition in the effluent of textile dye industry) within $16 \mathrm{hrs}$.
\end{abstract}

Key-words: Bacillus sp., Dye degradation, E. coli, Pseudomonas sp. SUK1, Plasmid, Transformation

\section{INTRODUCTION}

Textile dyeing effluents containing recalcitrant dyes are polluting water due to their color and by the formation of toxic or carcinogenic intermediates Such as aromatic amines from azo dyes [1,2]. Azo dyes are aromatic compounds with one or more- $\mathrm{N}=\mathrm{N}-\mathrm{Groups}$ and also the largest class of synthetic dye used at commercial level ${ }^{[3]}$ such as textile, food, paper making and cosmetic industries ${ }^{[4,5]}$. Microbial consortium was effectively used for degradation of different types of dyes ${ }^{[6]}$. In last decade more focus was given for the dye decolorization with fungal systems ${ }^{[7]}$.

\section{How to cite this article}

Jorgewad RM. Increasing Efficiency of the Dye Degrading Bacteria by Plasmid Transfer Method. SSR Inst. Int. J. Life Sci., 2019; 5(2): 2218-2223.



Access this article online https://iijls.com/
The general mechanism of bacterial dye degradation has triggered by azoreductase enzyme and related transport proteins. But unfortunately studies at genetic level for dye degrading proteins are rare. Thus far very few articles in literature were found dye decolorization by gene or plasmid transfer. Exogenous DNA transfer in to the recipient cell through DNA transformation can permanently or transiently alter the heredity ${ }^{[8]}$. To enhance dye degradation capacity of bacteria at genetic level, two strategies are generally preferred; (i) Using strains containing additional corresponding genes integration with chromosome and (ii) Using Plasmidcontaining strains or transformation of plasmid ${ }^{[9]}$. In this paper, we aimed to introduce a plasmid isolated from Pseudomonas sp. SUK1, E. coli and Bacillus sp. to obtain high efficient dye degrading, aerobic, and fast growing transformed organism. 


\section{MATERIALS AND METHODS}

This research work was carried out from January 2014 to November 2014. Pseudomonas sp. SUK1, which was a potential dye degrader under anoxic condition ${ }^{[10]}$ was obtained from the Department of Biochemistry, Shivaji University, Kolhapur, India and used in this study. Bacillus sp. was isolated from the effluent of textile dye industry using minimal agar medium. Luria Bertani (LB) broth and agar were used to propagate Pseudomonas sp. SUK1 strain at $37^{\circ} \mathrm{C}$ with anoxic condition. Bacterial cell lysis was performed by alkaline lysis method ${ }^{[11]}$. LB agar medium was supplemented with antimicrobial sensitivity testing with Himedia Combi VII octa disc for antibiotic resistance test and for the selection of transformed bacteria. LB agar plus $50 \mathrm{mg} \mathrm{l}^{-1}$ dye was used to detect the dye decolorization capacity i. e. degradation of the dye after incubation at $30^{\circ} \mathrm{C}$ for $24 \mathrm{hrs}$ in anoxic condition. Nutrient agar was used for the growth of recipient and transformed bacteria also for dye degradation.

A loopful of microbial culture was inoculated in $250 \mathrm{ml}$ capacity Erlenmeyer flask containing $100 \mathrm{ml}$ nutrient broth. After $24 \mathrm{hrs}$, dye was added at concentration 50 $\mathrm{mg} \mathrm{ml} \mathrm{m}^{-1}$. Aliquots of $3 \mathrm{ml}$ was withdrawn from culture media at different time intervals, centrifuged at 5000 rotation per minute (rpm) for $15 \mathrm{~min}$ and separated the bacterial cell mass.

Decolorization of dye was determined by measuring the absorbance of medium at respective optimal wavelength via colorimetric assay and percent decolorization was calculated as follows-

\section{Dye Decolorization $(\%)=$}

\section{Initial absorbance - Observed absorbance x 100}

\section{Initial absorbance}

Plasmid isolation was done using the miniprep method [11]. Plasmid analysis was performed on agarose gel electrophoresis and visualization by using Ethidium bromide as a staining dye ${ }^{[12]}$. Isolated plasmid DNA was eluted from agarose gel by melting agarose after visualization of DNA band. The isolated plasmid was transformed into competent cells of $E$. coli and Bacillus sp. by cold calcium chloride $\left(\mathrm{CaCl}_{2}\right)$ treatment method ${ }^{[13]}$. The transformant was selected on LB agar plates containing antibiotics disk and screened through antibiotic sensitivity test ${ }^{[14]}$. The transformant microbial colonies were designated as $E$. coli X1. In another LB agar plates containing antibiotics for Bacillus sp. was not show any growth on LB agar plate containing antibiotic disc.

Microorganisms and Cultivation- $E$. coli $\mathrm{X} 1$, transformed bacteria harboring plasmid was cultivated in nutrient agar containing antibiotic co-Trimoxzo at the concentration $200 \mathrm{ug} \mathrm{I}^{-1}$.

Measurement of dye concentration- Azo dye used in this study was Red BLI obtained from Manpas and Textile Dye Industry, Ichalkaranji, Maharashtra, India. The concentration of azo dye was measured by using double beam spectrophotometer and absorbance of supernatant of the media at $540 \mathrm{~nm}^{[15]}$.

Batch decolorization operations- In typical batch decolorization tests early stationary phase culture or 24 h grown E. coli X1 mixed with dye (Red BLI) to undertake bacterial decolorization under static condition with monitoring of dye at designated time interval. Unless stated otherwise, the dye concentration was $50 \mathrm{mg} \mathrm{l}^{-1}$. Physiological conditions like $\mathrm{pH}$ and temperature of the reaction solution were maintained 7 and $30^{\circ} \mathrm{C}$ respectively ${ }^{[16]}$.

\section{RESULTS}

The isolated bacterium was successfully transformed with the plasmid DNA of Pseudomonas sp. SUK1. Isolated plasmid and genomic DNA profile were observed on agarose gel electrophoresis (Fig. 1). The isolated plasmid was approximately 2000 base pairs (bp) in size after comparing with mid-range DNA ladder of 1000 bp. Antibiotic sensitivity assay shown co-Tromoxil can be used for selection of transformant. Therefore co-Tromoxil and other antibiotics was screened and used for detection of transformant (Fig. 2). Antibiotic resistant and sensitivity pattern was shown that recipient microorganism acquired resistant for co-Tromoxil lead to confirm the transfer of plasmid (Table 1). This technique was very useful in the process of gene transfer. Antibiotic screening markers are useful in genetic engineering and molecular biology.

Transformed microorganism E. coli X1 showed very high efficiency for dye degradation in aerobic conditions with an ambient temperature of $30^{\circ} \mathrm{C}$ in around $16 \mathrm{~h}$ with $96 \%$ degradation of Red BLI, 95\% for Navy Blue-HER, 94\% for Golden Yellow-HER as per Table 3. Also, it decolorized a mixture of 7 dyes with $82.54 \%$ decolorization (Fig. 3). 
Batch decolorization of dye Red BLI by the wild type E. decolorize Red BLI with $89.60 \%$ decolorization and also

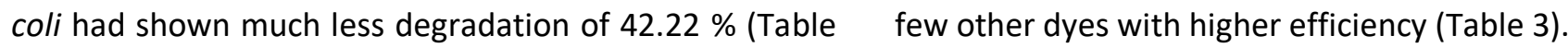

2). Comparatively, transformed E. coli was able to

Table 1: Antimicrobial sensitivity testing against microorganisms

Antibiotics

\section{Microorganisms}

Bacillus sp.

E. coli

Pseudomonas sp. SUK1

\begin{tabular}{cccc}
\hline Amoxycillin $(10 \mathrm{mcg})$ & $\mathrm{R}$ & $\mathrm{S}$ & $\mathrm{S}$ \\
Cloxacillin $(5 \mathrm{mcg})$ & $\mathrm{R}$ & $\mathrm{R}$ & $\mathrm{R}$ \\
Erthromycin $(\mathbf{1 5} \mathrm{mcg})$ & $\mathrm{S}$ & $\mathrm{S}$ & $\mathrm{S}$ \\
Tetracycline $(\mathbf{1 0} \mathrm{mcg})$ & $\mathrm{S}$ & $\mathrm{S}$ & $\mathrm{S}$ \\
Penicillin $(2 \mathrm{mcg})$ & $\mathrm{R}$ & $\mathrm{R}$ & $\mathrm{R}$ \\
Co-Trimoxzo $(25 \mathrm{mcg})$ & $\mathrm{S}$ & $\mathrm{S}$ & $\mathrm{R}$ \\
Penicillin V $(3 \mathrm{mcg})$ & $\mathrm{R}$ & $\mathrm{R}$ & $\mathrm{S}$ \\
Cephalexin $(30 \mathrm{mcg})$ & $\mathrm{S}$ & $\mathrm{S}$ & $\mathrm{R}$ \\
\hline
\end{tabular}

$\mathrm{R}=$ Antibiotic resistant, $\mathrm{S}=$ Antibiotic susceptible

Table 2: Dye decolorizing Capacity of E. coli (wild type)

\begin{tabular}{ccccc}
\hline & \multicolumn{2}{c}{ Time (h) } & \multicolumn{2}{c}{ Time (h) } \\
\cline { 2 - 5 } Dye & $\mathbf{2 4} \mathbf{h}$ & Decolorization (\%) & $\mathbf{4 8} \mathbf{h}$ & Decolorization (\%) \\
\hline Golden Yellow-HER & 0.174 & 28.68 & 0.127 & 47.95 \\
\hline Green HE-4BD & 1.011 & 3.80 & 1.003 & 4.57 \\
Navy Blue-HER & 0.480 & 29.20 & 0.333 & 50.88 \\
Yellow 4G & 0.183 & 29.06 & 0.150 & 41.86 \\
Red HEA & 0.198 & 26.39 & 0.163 & 39.40 \\
Reactive Orange TGLL & 0.355 & 18.58 & 0.246 & 43.58 \\
Red BLI & 0.520 & 42.22 & 0.490 & 45.55 \\
\hline
\end{tabular}




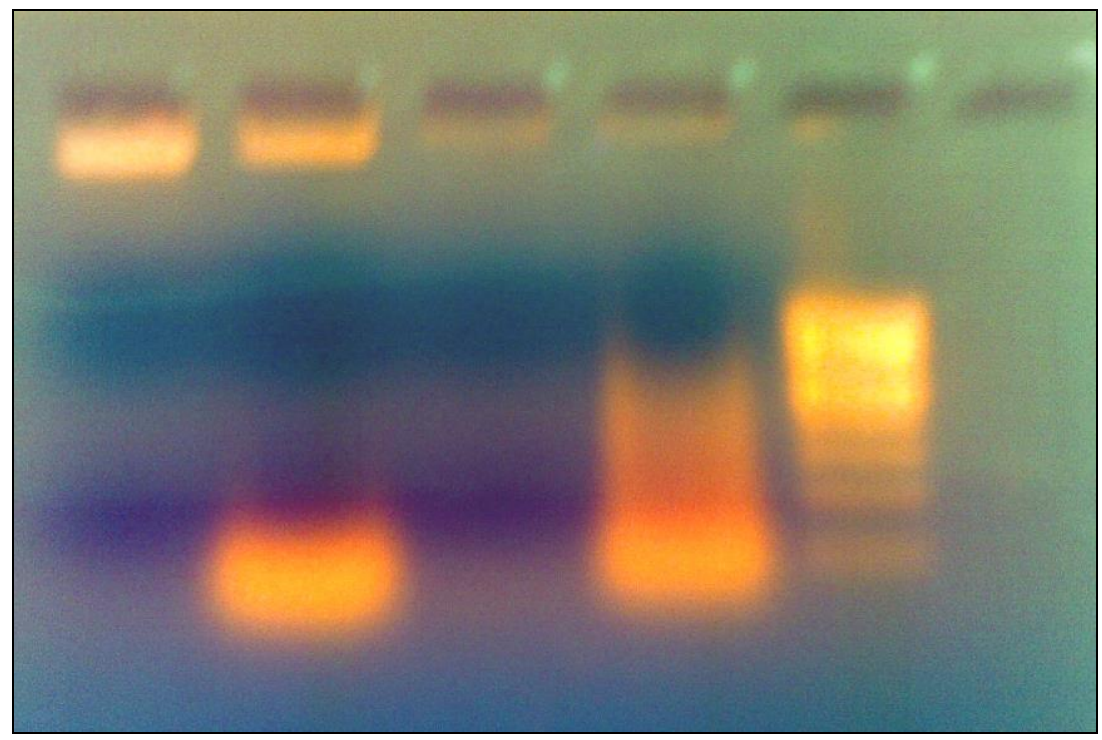

Fig. 1: DNA profile of Pseudomonas sp. SUK1 on 1\% Agarose gel electrophoresis Lane 1: Control DNA (48kb), Lane 2: Chromosomal DNA, Lane 3: Blank, Lane 4: Plasmid DNA ( 2000bp), Lane 5: 1000 bp ladder DNA

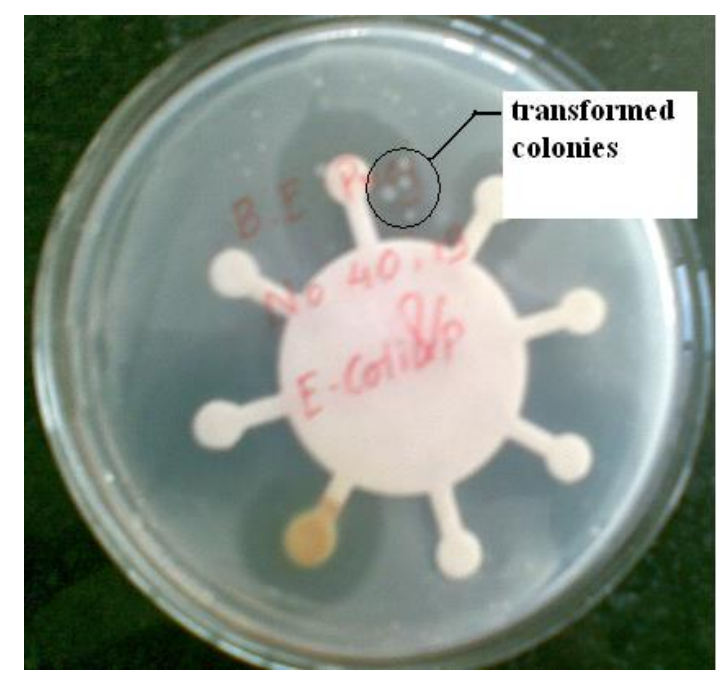

Fig. 2: E. coli genetically transformed colonies obtained with antibiotics as screening markers

Table 3: Decolorization of dyes by transformed E. coli

\begin{tabular}{ccccc}
\hline Dye & Wavelength $(\mathbf{n m})$ & Initial Reading & After $\mathbf{2 4} \mathbf{h}$ & Decolorization (\%) \\
\hline GoldenYellow-HER & 620 & 1.55 & 0.11 & $94.53 \%$ \\
Green HE-4BD & 550 & 1.90 & 0.27 & $85.50 \%$ \\
Navy Blue-HER & 430 & 1.88 & 0.12 & $95.10 \%$ \\
Yellow 4G & 420 & 1.79 & 0.14 & $91.63 \%$ \\
Red HEA & 680 & 1.91 & 0.15 & $92.00 \%$ \\
Reactive Orange TGLL & 620 & 1.56 & 0.45 & $71.23 \%$ \\
Red BLI & 540 & 1.80 & 0.16 & $96.11 \%$ \\
\hline
\end{tabular}




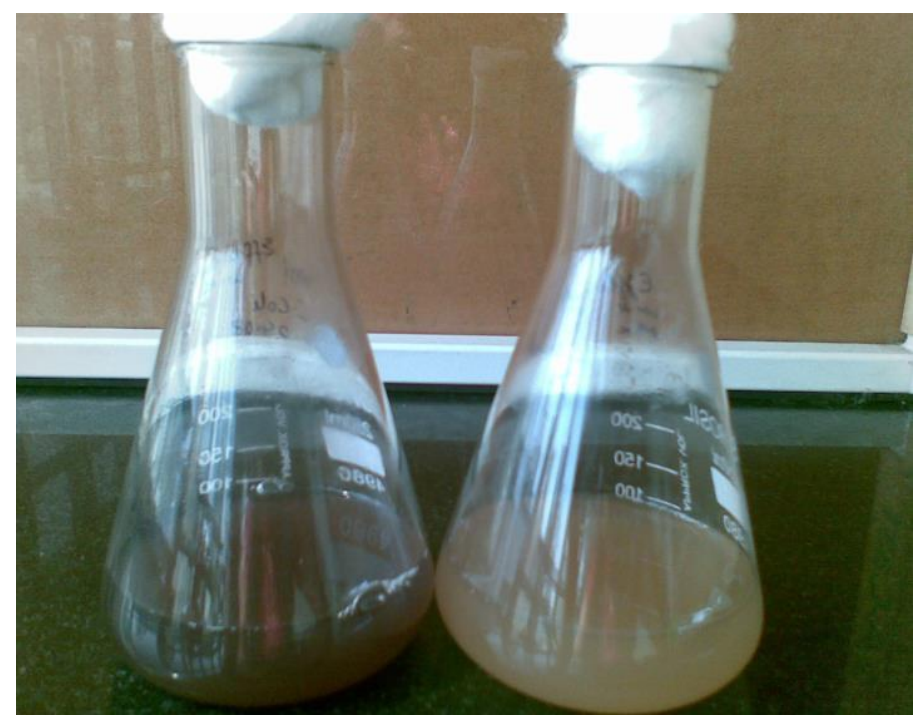

Fig. 3: Degradation of mixture of 7 dyes by transformed E. coli X1 (82.54 \%)

\section{DISCUSSION}

Pseudomonas sp. SUK1 is a facultative anaerobe and requires anaerobic conditions for degradation of dyes, whereas the transformed organisms can grow and degrade dyes aerobically. While E. coli was able to grow in effluent conditions but cannot degrade the dye efficiently. Therefore by transformation, fast growing ability of $E$. coli under effluent condition and the dye degrading capacity of Pseudomonas sp. SUK1 was combined in transformed bacteria which can be used directly in the effluent to treat it by degrading the dyes efficiently. Horizontal mobility of plasmid was a very often phenomenon in nature [17,18]. Most of Pseudomonas strains were carrying degrading plasmid for example Tol and IncP Plasmid ${ }^{[19]}$. Similarly, resistant plasmids were good source of screening marker as well as a useful bacterial DNA vector ${ }^{[20]}$. Bacterial plasmids pGNB1 and NAH7 can efficiently degrade dyes as well as transferable ${ }^{[21,22]}$. Advancement in this process was transfer of degrading plasmid in bacteria to make more efficient dye degrading transformant which was a prominent alternative as compared to conventional biodegradation process. Horizontal mobility of plasmid was used widely for finding multidrug resistance in pathogenic microorganisms. Therefore transformant $E$. coli X1 dye degrading efficiency was increased by more than two fold for textile dye Red BLI.

\section{CONCLUSIONS}

Therefore results indicated that transformed bacteria will be good and effective strain for biotransformation of the textile dyes. Plasmid transfer is also a natural process.

The transformed bacteria can degrade $50 \mathrm{mg} \mathrm{l}^{-1}$ of individual dyes and even a mixture of dyes (which is actually the condition in the effluent of textile dye industry) within $16 \mathrm{hrs}$. Thus, the transformed bacteria have in situ application where both the organisms were difficult to use.

In future genetically modified strains can be used more efficiently for effective and diverse carcinogenic dye degradation as compare to the wild type alternative source. Efforts need to be focused on dye degrading enzyme system manipulation at genetic level will be more efficient method in biodegradation. Enzyme immobilization and making a multi enzyme nano-flower system will be effective method for biodegradation. This will be the economical, as well as widely suitable method for small and large industrial scale effluent treatment plants.

\section{ACKNOWLEDGMENTS}

The author is very much thankful to Dr. Kalyani DC, Department of Biochemistry, Shivaji University, Kolhapur, India for providing pure culture of Microbial strain of Pseudomonas sp. SUK1.

\section{CONTRIBUTION OF AUTHORS}

All authors equally contributed in this article.

\section{REFERENCES}

[1] Heiss GS, Gowan B, Dabbs ER. Cloning of DNA from a Rhodococcus strain conferring the ability to 
decolourize sulfonated azo dyes. FEMS Microbiol. Lett., 1992; 99: 221-26.

[2] Spadaro JT, Gold MH, Renganathan V. Degradation of azo dyes by the lignin-degrading fungus Phanerochaete chrysosporium, Appl. Environ. Microbiol., 1992; 58: 2397-01.

[3] Zollinger, H, Colour Chemistry-Synthesis, Properties and Applications of Organic Dyes and Pigments. $\mathrm{VCH}$ Publishers, New York, 1987: 92-100.

[4] Chung KT, Stevens SE. Degradation of azo dyes by environmental microorganisms and helminthes, Environ. Toxicol. Chem., 1993; 12: 2121-32.

[5] Carliell CM, Barclay SJ, Naidoo N, Buckley CA, Mulholland DA, Senior E. Microbial decolourization of a reactive azo dye under anaerobic conditions, Water Sci. (Pretoria), 1995; 21: 61-69.

[6] Jadhav SU, Kalme SD, Govindwar SP. Biodegradation of Methyl red by Galactomyces geotrichum MTCC 1360. Int. Biodeterior Biodegradation, 2007; 62: 135-42.

[7] Parshetti GK, Kalme SD, Saratale GD, Govindwar SP. Biodegradation of Malachite green by Kocuria rosea MTCC 1532, Acta. Chim. Slov., 2006; 53: 492-98.

[8] Springael D, Top EM. Horizontal gene transfer and microbial adaptation to xenobiotics: new types of mobile genetic elements and lessons from ecological studies. Trends Microbiol., 2004; 12: 53-58.

[9] Kalyani DC, Patil PS, Jadhav JP, Govindwar SP. Biodegradation of reactive textile dye Red BLI by an isolated bacterium Pseudomonas sp. SUK1' Bioresour Technol., 2007; 99(11): 4635-41.

[10]Nishikawa M, Huang L. Nonviral vectors in the new millennium: delivery barriers in gene transfer. Hum. Gene Ther., 2001; 12: 861-870.

[11]Birnboim HC. A Rapid Alkaline Extraction Method for the Isolation of Plasmid DNA, Meth. Enzymol., 1983; 100: 243-55.

[12]Sambrook J, Fritsch EF, Maniatis T. Molecular cloning: a laboratory manual, $2^{\text {nd }}$ ed. Cold Spring Harbor Laboratory Press, Cold Spring Harbor, NY, 1989.
[13]Sambrook, J, Rusell DW. Protocols for plasmid isolation and transformation, Molecular cloning: a laboratory manual (Volume I), Cold Spring Harbour Lab Press NY, 2002.

[14]Clinical and Laboratory Standards Institute. Performance standards for antimicrobial susceptibility testing. $15^{\text {th }}$ informational supplement. M100-S16. Clinical and Laboratory Standards Institute, Wayne, PA, 2006.

[15]Turhan K, Ozturkcan SA. Decolorization and Degradation of Reactive Dye in Aqueous Solution by Ozonation in a Semi-Batch Bubble Column Reactor. Water Air Soil Pollut., 2013; 11: 1-13.

[16]Gudmalwar RM, Kamble LH. Biodegradation of reactive red 4E8Y5 by using Providencia sp. RMG1 and Bacillus sp. RMG2. Sci. Res. Re., 2012; 2(2): 178-88.

[17]Thomas CM, Nielsen KM. Mechanisms of, and barriers to, horizontal gene transfer between bacteria. Nat. Rev. Microbiol., 2005; 3: 711-21.

[18]Davison J. Genetic exchange between bacteria in the environment. Plasmid, 1999; 42: 73-91.

[19]SchlUter AR, PUhler SA, Top EM. Genomics of IncP-1 antibiotic resistance plasmids isolated from wastewater treatment plants provides evidence for a widely accessible drug resistance gene pool. FEMS Microbiol. Rev., 2007; 31: 449-77.

[20]Clewell DB. Antibiotic Resistance Plasmids in Bacteria. In: eLS. John Wiley \& Sons Ltd, Chichester, Feb: 2014.

[21] SchlUter A, Krahn I, Kollin F, BOnemann G, Stiens $M$, et al. IncP-1 $\beta$ Plasmid pGNB1 Isolated from a Bacterial Community from a Wastewater Treatment Plant Mediates Decolorization of Tri-phenyl methane Dyes. Appl. Environ. Microbiol. 2007; 73(20): 6345-50.

[22] Sota $M$, Yano $H$, Ono A, Miyazaki $R$, Ishii $H$, et al. Genomic and Functional Analysis of the IncP-9 Naphthalene-Catabolic Plasmid NAH7 and Its Transposon Tn4655 Suggests Catabolic Gene Spread by a Tyrosine Recombinase. J. Bacteriol., 2006; 188 (11): 4057-67. 